\title{
Seasonal variability in the grazing potential of the invasive amphipod Gammarus tigrinus and the native amphipod Gammarus salinus (Amphipoda: Crustacea) in the northern Baltic Sea
}

\author{
Helen Orav-Kotta $\cdot$ Jonne Kotta $\cdot$ \\ Kristjan Herkül · Ilmar Kotta · Tiina Paalme
}

Received: 3 August 2007 / Accepted: 14 April 2008/Published online: 23 April 2008

(C) The Author(s) 2008

\begin{abstract}
Mesograzers are known to reduce the biomass of their host plant and modify the structure of the whole macrophyte community in many ecosystems. Thus, the introduction of an efficient mesograzer may destabilize macrophyte community and also affect the native grazers. We estimated how large proportion of macrophyte production are consumed by the alien gammarid G. tigrinus and the native gammarid G. salinus in the species poor ecosystem of the northern Baltic Sea. We analysed whether G. tigrinus consumes different diet as the native G. salinus and whether the effect of G. tigrinus on the survival of the native G. salinus is macrophyte species specific. Grazing experiments showed that there was a clear difference in the grazing rates of gammarids among the studied macrophyte species in summer and autumn but not in spring. The grazing rates were significantly higher in the prevailing macrophyte Pilayella littoralis as compared to other macrophytes. The grazing was inversely related to the diurnal net photosynthetic values of macrophytes. The gammarid amphipods
\end{abstract}

H. Orav-Kotta $(\bowtie) \cdot$ J. Kotta $\cdot$ K. Herkül ·

I. Kotta $\cdot$ T. Paalme

Estonian Marine Institute, University of Tartu,

Mäealuse 10a, Tallinn 12618, Estonia

e-mail: helen.orav@sea.ee

K. Herkül

Institute of Zoology and Hydrobiology, University

of Tartu, Tartu, Estonia potentially removed only a minor part of plant primary production except for summer and autumn when grazing of a few perennial species exceeded macrophyte production. Macrophyte species and presence of G. salinus had no effect on the survival of G. tigrinus. The presence of G. tigrinus, however, reduced the survival of the native gammarids within $P$. littoralis in summer. To conclude it is likely that both native and alien gammarid amphipods do not exert significant pressure on the macroalgal communities in the northern Baltic Sea. Competitive interactions between G. tigrinus and G. salinus within the prevailing macrophyte $P$. littoralis is the likely explanation of the decline of the native gammarid amphipods after the establishment of G. tigrinus in the northern Baltic Sea.

Keywords Baltic Sea - Gammarus tigrinus . Gammarus salinus · Grazing · Mesoherbivore · Nonindigenous

\section{Introduction}

Temperate shores throughout the world are dominated by macrophytes (Foster et al. 2003; Schiel 2004). There exist many studies demonstrating that macrophyte communities affect the structure of associated fauna, especially mesoherbivore communities (Huntly 1991; Lawton 1994; Knowles and Bell 1998; Kotta and Orav 2001; Parker et al. 2001). On the other hand, 
mesoherbivores are known to affect their host plant and in some cases even modify the structure of the whole macroalgal assemblage (Cronin and Hay 1996; Duffy and Hay 2000; Karez et al. 2000). The biomasses of aquatic plants and mesoherbivores are positively correlated in many waterbodies as plant provides mesoherbivores habitat and food resources (Orav-Kotta 2004). Animals respond more strongly to the amount of available resource than the diversity of plants providing it (Parker et al. 2001) suggesting that mesoherbivores have often broad diet and selectivity is rare (Cruz-Rivera and Hay 2001). There is some evidence that mesoherbivores may feed directly on perennial macrophytes (Poore 1994; Viejo 1999; Karez et al. 2000). The majority of studies, however, indicate that mesoherbivores live within the bushes of perennial macrophytes and feed on the epiphytes attached to the host plant (Brawley and Adey 1981; D'Antonio 1985). This may be due to high nutritional value of the epiphytes but likely to the seasonal patterns of macrophyte communities. While the perennial macrophytes persist throughout the year, the ephemeral or filamentous species occur only seasonally (Nicotri 1980; Orth and Van Montfrans 1984; Arrontes 1990; Duffy 1990; Boström and Mattila 1999; Pavia et al. 1999).

The gammarid amphipods are ranked among the most important necto-benthic herbivores in many coastal seas. Gammarids have been recognized as both predators and herbivores (MacNeil et al. 1997, 1999), though, plants prevail in their diet (Kinne 1959). Earlier observations have indicated that grazing rates are dependent on the quality and quantity of food (Kinne 1959). A strong inverse relationship between algal productivity and mesoherbivore grazing suggests that gammarids prefer decomposing algae over fresh plants (Kotta et al. 2006). Besides, gammarids are known to graze algae more intensively than aquatic higher plants (Cyr and Pace 1993).

Due to low salinity and short evolutionary (geological) history the diversity is low in the Baltic Sea. Large and efficient herbivore species such as sea urchins, periwinkles or limpets are lacking and the low diverse communities are often dominated by resource generalists such as gammarid amphipods and idoteids (Salemaa 1979; Jormalainen et al. 2001; Orav-Kotta and Kotta 2003). The native Gammarus salinus Spooner and the invasive Gammarus tigrinus Sexton are the prevailing gammarid amphipods in the coastal range of the northern Baltic Sea (Hällfors et al. 1981; Herkül and Kotta 2007). Since the late 1990 and 2000s G. tigrinus significantly expanded its distribution in the Baltic Sea and currently threatens the integrity of mesoherbivore assemblages in the area (Jażdżewski et al. 2002; Leppäkoski et al. 2002; Szaniawska et al. 2003; Herkül and Kotta 2007). As gammarid amphipods are generally known to have a broad diet (Parker et al. 1993; Christie and Kraufvelin 2004) the studies on the feeding rates of gammarid amphipods on various algal diets are rare (Pascoe et al. 1995; Orav-Kotta and Kotta 2003, 2004; Kotta et al. 2006). There are some circumstantial evidence that G. tigrinus is competitively superior over G. salinus and most other native gammarid species in the European fresh and brackish waterbodies (e.g. Pinkster et al. 1992; Jażdżewski et al. 2002; Grabowski et al. 2006; Herkül and Kotta 2007). Providing different diets of native and invasive gammarids, shifting in the dominance of mesoherbivore communities may have profound consequences on macrophytes due to shift in the consumption of different macroalgal species. G. tigrinus may reduce the biomass of their host algae and indirectly favour those species that the native $G$. salinus are feeding on. On the other hand, the species structure of algal communities may influence the performance and survival of gammarid amphipods and, thus, may influence the outcome of competition between G. tigrinus and G. salinus in the Baltic Sea. Therefore, the aim of this paper was to investigate (1) how large proportion of macroalgal production are potentially consumed by $G$. tigrinus and G. salinus, (2) whether G. tigrinus consumes different diet as the native G. salinus and (3) whether the effect of G. tigrinus on the survival of the native $G$. salinus is macrophyte species specific. If $G$. tigrinus outcompetes $G$. salinus within certain macroalgal habitat, has different diet requirements as compared to G. salinus and consumes significant share of macroalgal production this invasion has a potential to facilitate or eliminate some native macroalgal and mesoherbivore species.

\section{Materials and methods}

The study was conducted in the shallow semienclosed Kõiguste Bay, Gulf of Riga, northern Baltic Sea $\left(58^{\circ} 22.10^{\prime} \mathrm{N} \quad 22^{\circ} 58.69^{\prime} \mathrm{E}\right)$. The prevailing 
sediment types of the bay area sandy clay mixed with pebbles, gravel or boulders. The prevailing depths are between 1 and $4 \mathrm{~m}$. The area is influenced by a diffuse nutrient load from the moderately eutrophicated Gulf of Riga (Astok et al. 1999). The benthic vegetation is well developed and extensive proliferation of ephemeral macroalgae and the appearance of drift algal mats have been reported from the area in the recent years (Paalme et al. 2004; Lauringson and Kotta 2006).

Grazing experiments were performed in Kõiguste Bay in May, July and September 2005. Depending on the natural occurrence of the macrophytes in the field different species were deployed in the experiment (Table 1). Macrophytes were collected from a shallow (1-3 m) area adjacent to Kõiguste Marine Biological Laboratory. Seven different macrophyte species were used in the grazing experiments: the brown algae Fucus vesiculosus L. and Pilayella littoralis (L.) Kjellm., the red alga Ceramium tenuicorne (Kütz.) Waern and Furcellaria lumbricalis (Huds.), the green algae Cladophora glomerata (L.) Kütz. and Enteromorpha intestinalis (L.) Nees. and the higher plant Myriophyllum spicatum L. Due to the intensive ice scour during preceding winter the perennial algae $F$. vesiculosus and F. lumbricalis were not found in spring. The alien G. tigrinus and the native $G$. salinus were collected at the same site either under the stones by means of handnet or within the stands of $F$. vesiculosus by shaking the algae. Only adult specimens were used in the experiment.

Grazing was studied in $5 \times 5 \times 20 \mathrm{~cm}$ nylon netbags of $1 \mathrm{~mm}$ mesh size. Each macroalgal treatment was added either six specimens of G. tigrinus, six specimens of $G$. salinus or three specimens of G. tigrinus and G. salinus. Three replicates of each

Table 1 Different macrophyte species used in the grazing experiments

\begin{tabular}{lccc}
\hline Macrophyte species & May & July & September \\
\hline Fucus vesiculosus & & + & + \\
Pilayella littoralis & & + & \\
Ceramium tenuicorne & & & + \\
Furcellaria lumbricalis & & + & + \\
Cladophora glomerata & & + & \\
Enteromorpha intestinalis & + & + & + \\
Myriophyllum spicatum & + & + & + \\
\hline
\end{tabular}

The choice of macrophyte species depended on their natural occurrence in the field treatment were used. Additionally, three control netbags contained algae relevant to each algal treatment and no amphipods. The wet weight of algae was determined prior to the experiment to the nearest of $0.01 \mathrm{~g}$. Before weighing the algae were gently dried on plotting paper until the paper did not become wet any more. Additional three replicates of each macroalgal treatment served as control to obtain the ratio of wet to dry weight. The algae were dried at $60^{\circ} \mathrm{C}$ during $48 \mathrm{~h}$. On average $0.2 \pm$ SE $0.02 \mathrm{~g} \mathrm{dw}$ of algae was deployed in each netbag. The biomass share of macrophytes to gammarids corresponded to the realistic densities in the field. The netbags were placed at $2 \mathrm{~m}$ depth about $0.5 \mathrm{~m}$ above the bottom. Each series of the experiment lasted 15-20 days. At the end of the experiment the test animals were counted, determined to species level and the dry weights of macroalgae were determined. Besides test animals, the netbags practically did not contain juvenile amphipods and other small grazers and the biomass of small grazers never exceeded $3 \%$ of biomass of the test animals. The changes in the dry weight of algae per number of gammarids in the nylon mesocosms served as the estimates of gammarid grazing in the field. These values were corrected to the weight increment due to the photosynthetic activity of the algae using the values of control netbags of grazing experiment (i.e. the treatment of no addition of gammarids). At the end of experiment the survival of gammarid amphipods within different macrophyte treatment was analysed.

In parallel to the grazing experiments, the in situ diurnal primary production of the studied macroalgal species was measured using the oxygen method (Köhler 1998). Small tufts (about $0.05 \mathrm{~g} \mathrm{dw}$ ) with no macroepiphytes and grazers (checked under a binocular microscope) were placed in $600 \mathrm{ml}$ glass bottles filled with sea water and incubated horizontally on trays at $0.5 \mathrm{~m}$ depth. Bottles without the algae served as controls. There were five replicates per treatment. Based on preliminary tests and suggestions from previous studies on different macroalgal species (Littler 1979) we assured that the bottles were large enough that depletion of nutrients or carbon did not occur. The changes in the dissolved oxygen concentration were measured by an oxygen meter OXI 92. The hourly net production rates were calculated from the differences in oxygen concentrations, measured over the incubation period (ca. 1-3 h). Daily net 
production rates were calculated as the sum of consecutive hourly net production rates and expressed as $\mathrm{mg} \mathrm{O}_{2} \mathrm{~g} \mathrm{dw}^{-1} 24 \mathrm{~h}^{-1}$. Dry weight of the algal material was determined after drying at $60^{\circ} \mathrm{C}$ for $48 \mathrm{~h}$. Based on the production estimates, all macroalgal species were photosynthetically active and no decomposition of the macroalgae occurred.

For univariate analyses the statistical programme "Statistica" was used (StatSoft Inc. 2004). The twoway-analyses of variance (ANOVAs) with gammarid and macrophyte species as factors were employed to describe their effect on gammarid grazing and survival. Due to notable seasonal differences in macrophyte species composition the analyses were run separately for each season. Post-hoc Bonferroni test was used to analyse which groups were statistically different from each other. The percentage data sets were arcsine transformed before statistical analysis.

\section{Results}

The photosynthetic activity of macrophytes varied among plant species and seasons. C. glomerata and $P$. littoralis had high diurnal net photosynthetic values above $100 \mathrm{mg} \mathrm{O}_{2} \mathrm{~g} \mathrm{dw}^{-1} 24 \mathrm{~h}^{-1}$. E. intestinalis had moderate values at $38-74 \mathrm{mg} \mathrm{O}_{2} \mathrm{~g} \mathrm{dw}^{-1} 24 \mathrm{~h}^{-1}$ and F. vesiculosus, F. lumbricalis, C. tenuicorne and M. spicatum had low values below $50 \mathrm{mg} \mathrm{O}_{2} \mathrm{~g} \mathrm{dw}^{-1}$ $24 \mathrm{~h}^{-1}$. The photosynthetic activity of macrophytes was highest in summer followed by values in spring and autumn. In general, invertebrate grazing was highest in summer, moderate in autumn and lowest in spring. The photosynthetic activity of macroalgae set the upper limits of gammarid grazing on macroalgae. The grazing was inversely related to the diurnal net photosynthetic values of macrophytes. With high photosynthetic values grazing was low. Both high and low grazing values were measured when the photosynthetic activity of algae was low (Fig. 1).

Grazing experiments showed a clear differences between the studied macrophyte species in summer and autumn and not in spring (two-way ANOVAs; the term of macrophyte species was significant at $P<0.001)$. In summer the grazing rates were significantly higher in $P$. littoralis as compared to $M$. spicatum, C. glomerata and F. lumbricalis (posthoc Bonferroni test $P<0.001$ ). In autumn the grazing

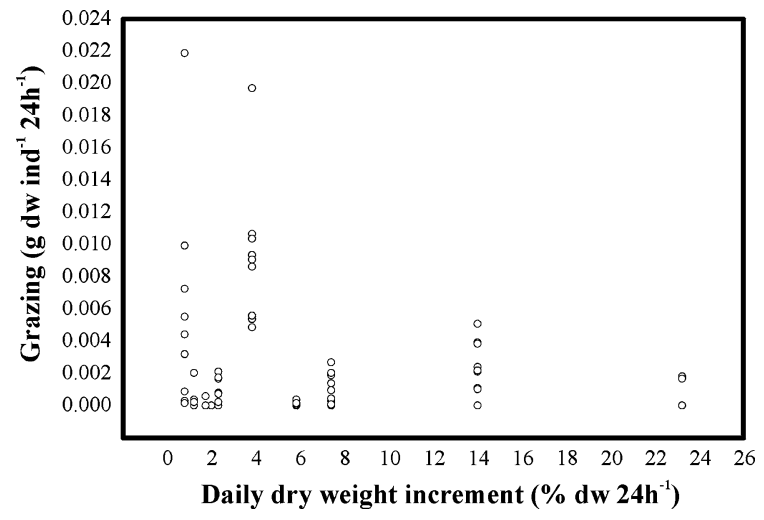

Fig. 1 Scatterplot between the daily dry weight increment of macrophytes and gammarid grazing

on E. intestinalis and F. lumbricalis exceeded the values of $M$. spicatum, $F$. vesiculosus and $C$. tenuicorne (post-hoc Bonferroni test $P<0.003$ ).

The species composition of gammarids had significant effect on grazing rates in spring and not in summer and autumn (two-way ANOVAs; $\left.P_{\text {spring }}=0.006, P_{\text {summer }}=0.095, P_{\text {autumn }}=0.057\right)$. The grazing rates in spring decreased in order of G. salinus $>$ G. salinus + G. tigrinus $>$ G. tigrinus. $G$. salinus grazed significantly more than $G$. tigrinus (post-hoc Bonferroni test $P=0.005$ ) whereas other differences were not significant (Fig. 2; Table 2).

In general macroalgal production exceeded mesoherbivore grazing. Only F. vesiculosus was overgrazed in summer and $F$. lumbricalis in autumn, respectively. The species composition of gammarids had significant effect on how much macrophyte production was removed in spring but not in summer and autumn (two-way ANOVAs; $P_{\text {spring }}=0.021$, $\left.P_{\text {summer }}=0.186, \quad P_{\text {autumn }}=0.093\right) . \quad G$. tigrinus removed less of macrophyte production as compared to $G$. salinus (post-hoc Bonferroni test $P=0.024$ ). The removal of macrophyte production was macrophyte species specific in all studied seasons (two-way ANOVAs; $\quad P_{\text {spring }}<0.001, \quad P_{\text {summer }}=0.016, \quad P_{\text {au- }}$ tumn $<0.001)$. Although M. spicatum was grazed less than E. intestinalis, the removal relative to plant production was higher for $M$. spicatum than E. intestinalis in spring (post-hoc Bonferroni test $P<0.001$ ). In summer the removal of $F$. vesiculosus was significantly higher than M. spicatum and C. glomerata (post-hoc Bonferroni test $P<0.02$ ) and in autumn the removal of $F$. lumbricalis was significantly higher 


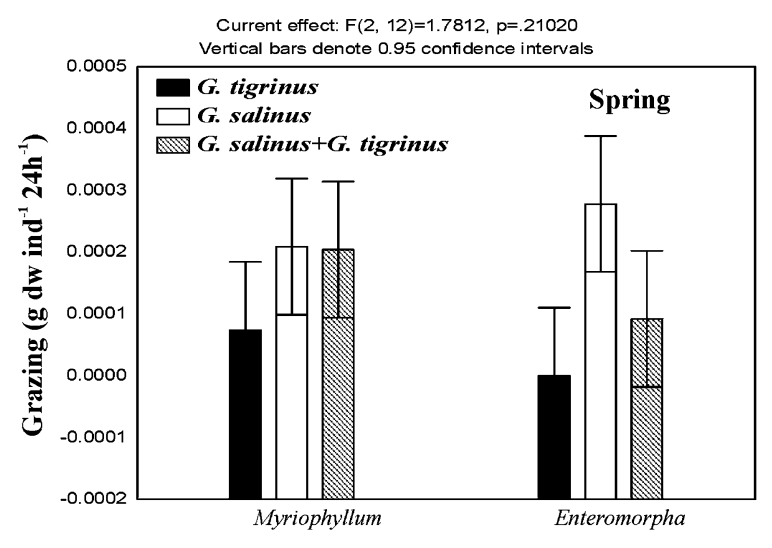

survival of G. salinus was higher in E. intestinalis than in M. spicatum (post-hoc Bonferroni test $P=0.039$ ). In summer the survival of G. salinus was high in E. intestinalis, $F$. vesiculosus and $M$. spicatum and low in C. glomerata, F. lumbricalis and P. littoralis. Significant differences were observed only between $E$. intestinalis and $P$. littoralis (post-hoc Bonferroni test $P=0.034$ ). Macrophyte species had no effect on the survival of $G$. tigrinus in the studied seasons (two-way ANOVAs; the term of macrophyte species was insignificant at $P<0.05$ ).

The presence of $G$. salinus had no impact on the survival of G. tigrinus regardless of macrophyte species (two-way ANOVAs; all factors and interactions not significant at $P>0.05$ ). The presence of G. tigrinus, however, reduced the survival of the native gammarids in summer (two-way ANOVAs; the term of gammarid species was significant at $P=0.023$ ). This difference was significant in $P$. littoralis (post-hoc Bonferroni test $P=0.033$ ) but not in other macrophytes (Fig. 4; Table 3). All interaction terms in the models of amphipod grazing and survival were insignificant.

\section{Discussion}

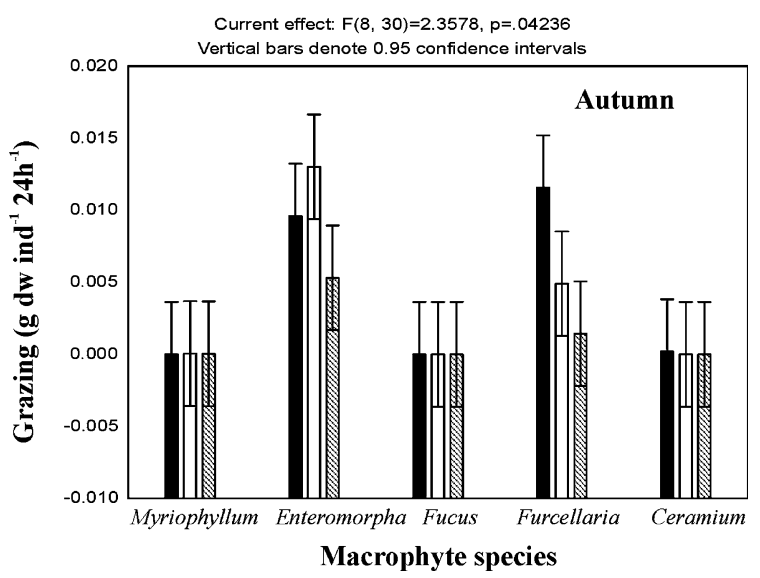

Fig. 2 Gammarid grazing on different macrophyte species in different seasons

than other macrophytes (post-hoc Bonferroni test $P<0.035$ ) (Fig. 3).

Macrophyte species had significant effect on the survival of G. salinus in spring and summer and not in autumn (two-way ANOVAs; $P_{\text {spring }}=0.039$, $\left.P_{\text {summer }}=0.013, P_{\text {autumn }}=0.211\right)$. In spring the

In general the grazing rates of G. salinus and G. tigrinus on macrophytes were similar. Only in spring G. salinus had higher grazing rates than G. tigrinus. Therefore it is plausible that recent shift from G. salinus dominated communities to G. tigrinus dominated communities with no marked change in total amphipod biomasses (Herkül and Kotta 2008) results decline in the grazing pressure of macroalgal communities in spring, namely on the green alga E. intestinalis. Although G. salinus is able to remove only $40 \%$ of algal production, it is important to stress here that E. intestinalis has low biomasses and small spatial extent in spring as the species is within its early stage of the annual succession (Kiirikki and Lehvo 1997; Kotta et al. 2006). Therefore G. salinus may actually control the development of E. intestinalis in spring, especially within smaller patches where gammarids have a potential to deplete the algal species (Lotze et al. 1999). Removal of the efficient grazers may disrupt this natural equilibrium and initiate extensive blooms of E. intestinalis. When macroalgal communities have already built up then 
Table 2 Homogeneous groups in terms of gammarid grazing on macrophytes in different seasons obtained from the post-hoc Bonferroni test of 2-way ANOVA analyses

\begin{tabular}{l}
\hline Gammarid treatment \\
\hline Spring \\
G. tigrinus \\
G. tigrinus \\
G. salinus + G. tigrinus \\
G. salinus + G. tigrinus \\
G. salinus \\
G. salinus
\end{tabular}

Summer

G. tigrinus
G. salinus
G. salinus
G. salinus + G. tigrinus
G. salinus + G. tigrinus
G. salinus
G. salinus + G. tigrinus
G. salinus + G. tigrinus
G. tigrinus
G. salinus
G. salinus + G. tigrinus
G. tigrinus
G. tigrinus
G. salinus
G. tigrinus
G. salinus + G. tigrinus
G. salinus
G. tigrinus

Autumn
G. tigrinus
G. salinus + G. tigrinus
G. tigrinus
G. salinus
G. salinus
G. salinus $+G$. tigrinus
G. salinus + G. tigrinus
G. salinus
G. tigrinus
G. salinus + G. tigrinus
G. salinus
G. salinus + G. tigrinus
G. tigrinus
G. tigrinus
G. salinus

Algal treatment

Mean grazing

Enteromorpha

Myriophyllum

Enteromorpha

Myriophyllum

Myriophyllum

Enteromorpha

Myriophyllum

Cladophora

Myriophyllum

Myriophyllum

Furcellaria

Furcellaria

Enteromorpha

Cladophora

Furcellaria

Fucus

Fucus

Enteromorpha

Cladophora

Enteromorpha

Fucus

Pilayella

Pilayella

Pilayella

Myriophyllum

Fucus

Fucus

Ceramium

Fucus

Ceramium

Myriophyllum

Myriophyllum

Ceramium

Furcellaria

Furcellaria

Enteromorpha

Enteromorpha

Furcellaria

Enteromorpha

0.0000
0.0001
0.0001
0.0002
0.0002
0.0003

0.0000

0.0000

0.0000

0.0001

0.0001

0.0001

0.0005

0.0006

0.0007

0.0008

0.0010

0.0012

0.0012

0.0016

0.0017

0.0018

0.0021

0.0034

0.0000

0.0000

0.0000

0.0000

0.0000

0.0000

0.0000

0.0000

0.0002

0.0014

0.0049

0.0053

0.0096

0.0116

0.0130
G1

G2

****

*****

*****

***** $\quad * * * *$

$* * * *$

$* * * *$

$* * * *$

$* * * *$

$* * * *$

$\begin{array}{ll}* * * * & \\ * * * * & \\ * * * * & \\ * * * * & \\ * * * * & \\ * * * * & \\ * * * * & * * * * \\ * * * * & * * * * \\ * * * * & * * * * \\ * * * * & * * * * \\ * * * * & * * * * \\ * * * * & * * * * \\ * * * * & * * * * \\ * * * * & * * * * \\ * * * * & * * * * \\ * * * * & * * * * \\ * * * * & * * * * \\ & * * * \\ & \end{array}$

$* * * *$

$* * * *$

**** $*$

$* * * *$

$* * * *$

$* * * *$

$* * * *$

$* * * *$

$* * * *$

$* * * *$

$* * * *$

$* * * *$

$* * * *$

$* * * *$

$* * * *$

$* * * *$

$* * * *$

$* * * *$

the grazing potential of mesoherbivores is too low to induce any significant losses of macroalgal communities (this study and Kotta et al. 2006).

The grazing of gammarids varied among algae. Among filamentous algae the gammarids grazed more on $P$. littoralis and E. intestinalis than 

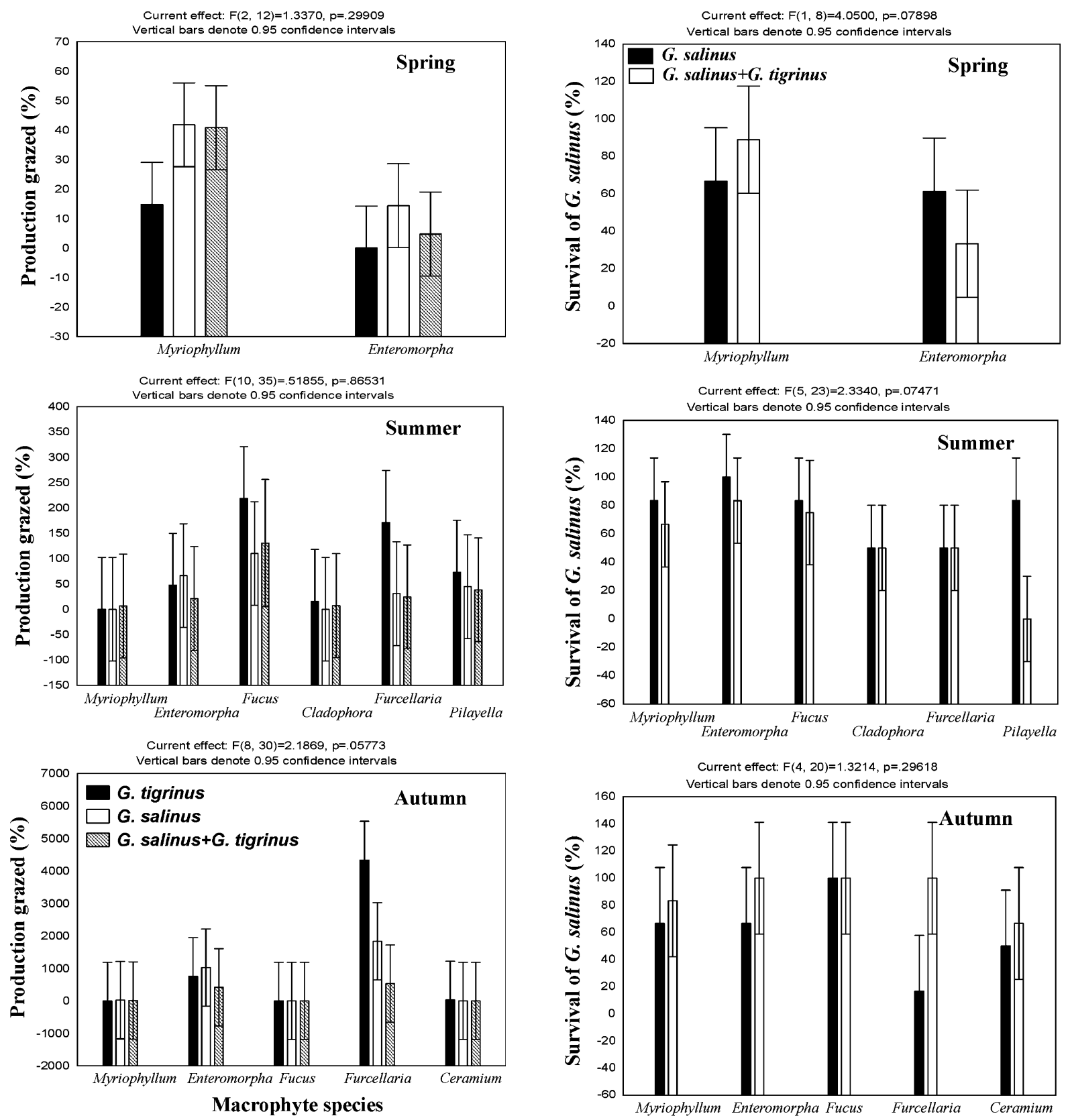

Fig. 3 Percentage of macrophyte production consumed by gammarids in different seasons

C. glomerata and C. tenuicorne. Among larger macroalgal species the amphipods grazed more on $F$. lumbricalis than $F$. vesiculosus. The higher plant M. spicatum was practically not consumed by the studied gammarids. It has been suggested that the food selection of mesoherbivores is relatively unresponsive to algal nutritional quality due to compensatory

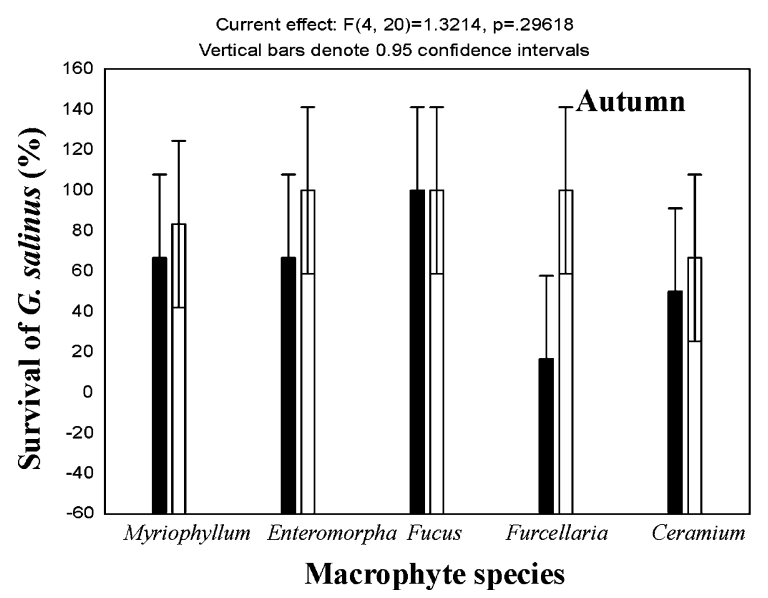

Fig. 4 Gammarid survival within different macrophyte species in different seasons

feeding that allows the mesoherbivores to exploit a variety of algal foods (Cruz-Rivera and Hay 2001). In general gammarids seem to forage almost everywhere and all types of macrophytes (Fenchel and Kolding 1979; Parker et al. 1993; Christie and Kraufvelin 2004). Our study also demonstrated that G. salinus 
Table 3 Homogeneous groups in terms of the survival of $G$. salinus among macrophytes in different seasons obtained from the post-hoc Bonferroni test of 2-way ANOVA analyses

**** $P<0.05$

\begin{tabular}{|c|c|c|c|c|}
\hline Gammarid treatment & Algal treatment & Mean survival & G1 & G2 \\
\hline \multicolumn{5}{|l|}{ Spring } \\
\hline G. salinus + G. tigrinus & Enteromorpha & 33 & $* * * *$ & \\
\hline G. salinus & Enteromorpha & 61 & $* * * *$ & \\
\hline G. salinus & Myriophyllum & 67 & $* * * *$ & \\
\hline G. salinus + G. tigrinus & Myriophyllum & 89 & $* * * *$ & \\
\hline \multicolumn{5}{|l|}{ Summer } \\
\hline G. salinus + G. tigrinus & Pilayella & 0 & & $* * * *$ \\
\hline G. salinus + G. tigrinus & Cladophora & 50 & $* * * *$ & $* * * *$ \\
\hline G. salinus & Cladophora & 50 & $* * * *$ & $* * * *$ \\
\hline G. salinus & Furcellaria & 50 & $* * * *$ & $* * * *$ \\
\hline G. salinus + G. tigrinus & Furcellaria & 50 & $* * * *$ & $* * * *$ \\
\hline G. salinus + G. tigrinus & Myriophyllum & 67 & $* * * *$ & $* * * *$ \\
\hline G. salinus + G. tigrinus & Fucus & 75 & $* * * *$ & $* * * *$ \\
\hline G. salinus + G. tigrinus & Enteromorpha & 83 & $* * * *$ & \\
\hline G. salinus & Fucus & 83 & $* * * *$ & \\
\hline G. salinus & Myriophyllum & 83 & $* * * *$ & \\
\hline G. salinus & Pilayella & 83 & $* * * *$ & \\
\hline G. salinus & Enteromorpha & 100 & $* * * *$ & \\
\hline \multicolumn{5}{|l|}{ Autumn } \\
\hline G. salinus & Furcellaria & 17 & $* * * *$ & \\
\hline G. salinus & Ceramium & 50 & $* * * *$ & \\
\hline G. salinus + G. tigrinus & Ceramium & 67 & $* * * *$ & \\
\hline G. salinus & Enteromorpha & 67 & $* * * *$ & \\
\hline G. salinus & Myriophyllum & 67 & $* * * *$ & \\
\hline G. salinus + G. tigrinus & Myriophyllum & 83 & $* * * *$ & \\
\hline G. salinus + G. tigrinus & Fucus & 100 & $* * * *$ & \\
\hline G. salinus + G. tigrinus & Furcellaria & 100 & $* * * *$ & \\
\hline G. salinus + G. tigrinus & Enteromorpha & 100 & $* * * *$ & \\
\hline G. salinus & Fucus & 100 & $* * * *$ & \\
\hline
\end{tabular}

and G. tigrinus are capable of foraging different types of food, however, when the filamentous brown alga $P$. littoralis was present it seemed to be the most important diet of the studied gammarids.

The grazing pressure of mesoherbivores changed with season that is consistent to the earlier observations (Duffy and Hay 1994; Kennish 1997; OravKotta and Kotta 2003; Kotta et al. 2006). Our study showed statistical differences in the grazing of different macrophytes both in warm (summer) and cold season (autumn). The lack of macrophyte specific feeding of gammarids in spring may be attributed to low grazing rates and low number of macrophyte species available in spring. However, when the grazing was partitioned among gammarid species then at least $G$. salinus showed a clear difference in grazing among macrophyte species.

The survival of G. salinus differed among macrophytes in spring and summer. The plant morphology (filamentous vs. coarse thallus), high taxonomic level (distinction of green, brown, red alga, higher plant), plant photosynthetic rate failed to explain the survival of G. salinus. Cruz-Rivera and Hay (2001) demonstrated that the survival of amphipods was low on Cladophora and that was also confirmed to our study, though, the difference was not statistically significant. Instead the survival of $G$. salinus was very low in $P$. littoralis. However, this figure actually reflects a strong negative effect of G. tigrinus on G. salinus within P. littoralis. 
Following the increasing eutrophication the biomass of ephemeral algae especially $P$. littoralis have increased tremendously in the last decades and currently $P$. littoralis prevails in the northern Baltic Sea (Rönnberg et al. 1992; Karez et al. 2000; Kotta et al. 2000; Lauringson and Kotta 2006). In concurrent with filamentous algal blooms the diversity of macroalgal species has significantly declined (Rönnberg et al. 1992; Kotta et al. 2006). Our experiments and earlier studies have shown that among dominant macrophytes $P$. littoralis is the most rewarding food for mesoherbivores in the northern Baltic Sea (Kotta et al. 2000, 2006; Orav-Kotta and Kotta 2004). Hence, we may expect stronger competition for this resource in the study area. Our experiments showed that the presence of $G$. tigrinus induced higher mortality of G. salinus within P. littoralis. Thus, $G$. tigrinus has a potential to outcompete $G$. salinus within $P$. littoralis dominated macrophyte beds. Consequently, the recent blooms of $P$. littoralis are expected to induce a shift from $G$. salinus dominated communities to G. tigrinus dominated communities in the coastal range of the northern Baltic Sea. This is also consistent with the field data of increasing biomass shares of $P$. littoralis and G. tigrinus in recent years (Lauringson and Kotta 2006; Herkül and Kotta 2007).

The ratio of gammarid grazing to algal productivity determines the effects of the mesoherbivores on the algal communities. Our study showed that the gammarid amphipods grazed more likely filamentous algae than perennial species. Similar findings in other waterbodies (Brawley and Adey 1981; D'Antonio 1985) suggest that mesoherbivores may facilitate the persistence of perennial species by removing the epiphytic algae. However, our study also showed that the share of opportunistic algae, that the studied gammarid amphipods are potentially able to remove, is negligible in relation to the production of epiphytic algae. Thus, the gammarids are likely not able to reverse the blooms of ephemeral algae. As an exception mesoherbivore grazing occasionally exceeded macroalgal production within $F$. vesiculosus and F. lumbricalis. Thus, when the blooms of ephemeral algae are over (usually in late summer or autumn), gammarid density is high and epiphyte biomass is low gammarids may severely damage their host plant. In other seasons, however, gammarids do not exert significant pressure on the macroalgal communities in the northern Baltic Sea. Outside of the Baltic Sea mesoherbivores are known to largely control the dynamics of macroalgal assemblages (Menge et al. 1997; Worm and Sommer 2000). This regional difference may be attributed to the lack of effective grazers in our study area but more likely to very high level of abiotic disturbances e.g. ice scrape, dashing of waves, low oxygen levels and salinity (Kotta et al. 2008). The variability in abiotic conditions mainly determine broad patterns and dynamics of algal communities and the biotic interactions e.g. grazers effects on macrophytes operate at small scales and are weak in comparison to abiotic forcing in the Baltic Sea (Salemaa 1979; Malm et al. 1999; Engkvist et al. 2000; Malm and Kautsky 2003; Herkül et al. 2006; Kotta et al. 2006). Mesograzers have only shown to have deleterious effects on macrophyte populations when the density of grazers are abnormally high (Fralick et al. 1974; Kangas et al. 1982; Arrontes 1999; Kotta et al. 2000). More likely food type is a prime factor that determines the presence of grazer in macrophyte assemblages (Brawley 1992; Boström and Mattila 1999) and the seasonal biomass cycle of the macrophyte species is likely to explain the fluctuation of gammarid amphipods in field.

The invasion of G. tigrinus into the Baltic Sea area is truly exceptional as it is the only alien herbivorous amphipod originating from America (i.e. it is a ballast water species). All other non-native amphipods invaded the Baltic Sea from the Ponto-Caspian region. Either artificial connections between different waterbasins or intentional introductions as a fish food resource in different water reservoirs connected to the Baltic Sea opened a route of this massive migration (Arbaciauskas 2002; Leppäkoski et al. 2002). The most invasive among the Ponto-Caspian species Pontogammarus robustoides (Sars) and Obesogammarus crassus (Sars) are very abundant in the southern Baltic Sea (Grabowski et al. 2007). In the northern Baltic Sea, however, these species have not yet established or have very localized distribution (Herkül and Kotta 2007). Besides, the amphipod Gmelinoides fasciatus (Stebbing) from the Lake Baikal has been extremely successful in big freshwater basins adjacent to the Baltic Sea such as the Lake Peipsi (Timm et al. 1996) but the species has not established in the Baltic Sea area. Thus, in a near future other major shifts in macrophyte-herbivore 
assemblages are expected together with the retreat of $G$. tigrinus and the establishment of $P$. robustoides and $O$. crassus. As the effects of these species on native amphipods and macrophytes are not known it is difficult to predict whether such invasions reverse previous state or shift the ecosystem into a new state.

Acknowledgements This study was financed by the Estonian Target Financing Program SF 0180013s03, Estonian Science Foundation grants Nos 6015 and 6016. The experiments comply with the current laws of the country in which they were performed.

Open Access This article is distributed under the terms of the Creative Commons Attribution Noncommercial License which permits any noncommercial use, distribution, and reproduction in any medium, provided the original author(s) and source are credited.

\section{References}

Arbaciauskas K (2002) Ponto-caspian amphipods and mysids in the inland waters of Lithuania: history of introduction, current distribution and relations with native malacostracans. In: Leppäkoski E, Gollasch S, Olenin S (eds) Invasive aquatic species of Europe. Distribution, impacts and management. Kluwer Academic Publishers, Dordrecht, pp 104-115

Arrontes J (1990) Diet, food preference and digestive efficiency in intertidal isopods inhabiting macroalgae. J Exp Mar Biol Ecol 139:231-249

Arrontes J (1999) On the evolution of interactions between marine mesoherbivores and algae. Bot Mar 42:137-155

Astok V, Otsmann M, Suursaar Ü (1999) Water exchange as the main physical process in semi-enclosed marine systems: the Gulf of Riga case. Hydrobiologia 393:11-18

Boström C, Mattila J (1999) The relative importance of food and shelter for seagrass-associated invertebrates: a latitudinal comparison of habitat choice by isopod grazers. Oecologia 120:162-170

Brawley SH (1992) Mesoherbivores. In: John DM, Hawkins SJ, Price JH (eds) Plant-animal interactions in the marine benthos. Syst Assoc Special 46:235-263

Brawley SH, Adey WH (1981) Micrograzers may affect macroalgal density. Nature 292:177

Christie H, Kraufvelin P (2004) Mechanisms regulating amphipod population density within macroalgal communities with low predator impact. Sci Mar 68:189-198

Cronin G, Hay ME (1996) Effects of light and nutrient availability on the growth, secondary chemistry and resistance to herbivory of two brown seaweeds. Oikos 77:93-106

Cruz-Rivera E, Hay ME (2001) Macroalgal traits and the feeding and fitness of an herbivorous amphipod: the roles of selectivity, mixing, and compensation. Mar Ecol Prog Ser 218:249-266

Cyr H, Pace ML (1993) Magnitude and patterns of herbivory in aquatic and terrestrial ecosystems. Nature 361:148-150
D'Antonio C (1985) Epiphytes on the rocky intertidal red alga Rhodomela larix (Turner) C. Agardh: negative effects on the host and food for herbivores? J Exp Mar Biol Ecol $86: 197-218$

Duffy JE (1990) Amphipods on seaweeds: partners or pests? Oecologia 83:267-276

Duffy JE, Hay ME (1994) Herbivore resistance to seaweed chemical defence: the roles of mobility and predation risk. Ecology 75(5):1304-1319

Duffy JE, Hay ME (2000) Strong impacts of grazing amphipods on the organization of a benthic community. Ecol Monogr 70:237-263

Engkvist R, Malm T, Tobiasson S (2000) Density dependent grazing effects by the isopod Idotea baltica L. on Fucus vesiculosus L. in the Baltic Sea. Aquat Ecol 34:253-260

Fenchel TM, Kolding S (1979) Habitat selection and distribution patterns of five species of the amphipod genus Gammarus. Oikos 33:316-322

Foster MS, Nigg EW, Kiguchi LM, Hardin DD, Pearse JS (2003) Temporal variation and succession in an algaldominated high intertidal assemblage. J Exp Mar Biol Ecol 289:15-39

Fralick RA, Turgeon KW, Mathieson AC (1974) Destruction of kelp populations by Lacuna vincta (Montagu). Nautilus 88(4): $112-114$

Grabowski M, Konopacka A, Jażdżewski K, Janowska E (2006) Invasions of alien gammarid species and retreat of natives in the Vistula Lagoon (Baltic Sea, Poland). Helgoland Mar Res 60:90-97

Grabowski M, Jażdżewski K, Konopacka A (2007) Alien Crustacea in polish waters-Amphipoda. Aquat Inv 2:25-38

Hällfors G, Niemi A, Ackefors H, Lassig J, Leppäkoski E (1981) Biological oceanography. In: Voipio A (ed) The Baltic Sea, vol 30. Elsevier oceanography series, Amsterdam, pp 219-274

Herkül K, Kotta J (2007) New records of the amphipods Chelicorophium curvispinum, Gammarus tigrinus, G. duebeni, and G. lacustris in the Estonian coastal sea. Proc Estonian Acad Sci Biol Ecol 56:290-296

Herkül K, Kotta J, Kotta I, Orav-Kotta H (2006) Effects of physical disturbance, isolation and key macrozoobenthic species on community development, recolonisation and sedimentation processes. Oceanologia 48(S):267-282

Huntly N (1991) Herbivores and the dynamics of communities and ecosystems. Annu Rev Ecol Syst 22:447-503

Jażdżewski K, Konopacka A, Grabowski M (2002) Four PontoCaspian and one American gammarid species (Crustacea, Amphipoda) recently invading Polish waters. Contrib Zool 71:115-122

Jormalainen V, Honkanen T, Heikkilä N (2001) Feeding preferences and performance of a marine isopod on seaweed hosts: cost of habitat specialization. Mar Ecol Prog Ser 220:219-230

Kangas P, Autio H, Hällfors G, Luther H, Niemi A, Salemaa H (1982) A general model of the decline of Fucus vesiculosus at Tvärminne, South Coast of Finland in 1977-81. Acta Bot Fenn 118:1-27

Karez R, Engelbert S, Sommer U (2000) 'Co-consumption' and 'protective coating': two new proposed effects of epiphytes on their macroalgal hosts in mesograzer-epiphyte-host interactions. Mar Ecol Prog Ser 205:85-93 
Kennish R (1997) Seasonal patterns of food availability: Influences on the reproductive output and body condition the herbivorous crab Grapsus albolineatus. Oecologia 109(2):209-218

Kiirikki M, Lehvo A-M (1997) Life strategies of filamentous algae in the northern Baltic Proper. Sarsia 82:259-267

Kinne O (1959) Ecological data on the amphipod Gammarus duebeni. A monograph. Veröff Inst Meeresforsch Bremerh 6:117-202

Knowles LL, Bell SS (1998) The influence of habitat structure in faunal-habitat associations in a Tampa Bay segrass system, Florida. Bull Mar Sci 62:781-794

Köhler J (1998) Measurement of photosynthetic oxygen production. Rostock Meeresbiol Beitr 6:17-21

Kotta J, Orav H (2001) Role of benthic macroalgae in regulating macrozoobenthic assemblages in the Väinameri (north-eastern Baltic Sea). Ann Zool Fenn 31:163-171

Kotta J, Paalme T, Martin G, Mäkinen A (2000) Major changes in macroalgae community composition affect the food and habitat preference of Idotea baltica. Int Rev Hydrobiol 85:693-701

Kotta J, Orav-Kotta H, Paalme T, Kotta I, Kukk H (2006) Seasonal changes in situ grazing of the mesoherbivores Idotea baltica and Gammarus oceanicus on the brown algae Fucus vesiculosus and Pylaiella littoralis in the central Gulf of Finland, Baltic Sea. Hydrobiologia 554:117-125

Kotta J, Lauringson V, Martin G, Simm M, Kotta I, Herkül K, Ojaveer H (2008) Gulf of Riga and Pärnu Bay. In: Schiewer U (ed) Ecology of Baltic coastal waters. Springer. Ecol Stud 197:217-243

Lauringson V, Kotta J (2006) Influence of the thin drift algal mats on the distribution of macrozoobenthos in Kõiguste Bay, NE Baltic Sea. Hydrobiologia 554:97-105

Lawton JH (1994) What do species do in ecosystems? Oikos 71:367-374

Leppäkoski E, Olenin S, Gollasch S (2002) The Baltic Sea-a field laboratory for invasion biology. In: Leppäkoski E, Gollasch S, Olenin S (eds) Invasive aquatic species in Europe. Distribution, impacts and management. Kluwer Academic Publishers, Dordrecht, pp 253-259

Littler MM (1979) The effect of bottle volume, thallus weight, oxygen saturation levels, and water movement on apparent photosynthetic rates in marine algae. Aquat Bot 7:21-34

Lotze HK, Schramm W, Schories D, Worm B (1999) Control of macroalgal blooms at early developmental stages: Pilayella littoralis versus Enteromorpha spp. Oecologia 119:46-54

MacNeil C, Dick JTA, Elwood RW (1997) The trophic ecology of freshwater Gammarus (Crustacea: Amphipoda); problems and perspectives concerning the functional feeding group concept. Biol Rev 72:349-364

MacNeil C, Elwood RW, Dick JTA (1999) Differential microdistributions and interspecific interactions in coexisting Gammarus and Crangonyx amphipods. Ecography 22:415-423

Malm T, Kautsky L (2003) Differences in life-history characteristics and consistent with the vertical distribution pattern of Fucus serratus and Fucus vesiculosus (Fucales, Phaeophyceae) in the central Baltic Sea. J Phycol 39:880-887
Malm T, Engkvist R, Kautsky L (1999) Grazing effects of two freshwater snails on juvenile Fucus vesiculosus in the Baltic Sea. Mar Ecol Prog Ser 188:63-71

Menge BA, Daley BA, Wheeler PA, Dahlhoff E, Sanford E, Strub PT (1997) Benthic pelagic links and rocky intertidal communities: bottom-up effects and top-down control? Proc Natl Acad Sci USA 94:14530-14535

Nicotri ME (1980) Factors involved in herbivore food preference. J Exp Mar Biol Ecol 42:13-26

Orav-Kotta H (2004) Habitat choice and feeding activity of benthic suspension feeders and mesograzers in the northern Baltic Sea. Dissertation, University of Tartu

Orav-Kotta H, Kotta J (2003) Seasonal variations in the grazing of Gammarus oceanicus, Idotea baltica and Palaemon adspersus on benthic macroalgae. Proc Estonian Acad Sci Biol Ecol 52:141-148

Orav-Kotta H, Kotta J (2004) Food and habitat choice of the isopod Idotea baltica in the northeastern Baltic Sea. Hydrobiologia 514:79-85

Orth RJ, Van Montfrans J (1984) Epiphyte-seagrass relationships with an emphasis on the role of micrograzing: a review. Aquat Bot 18:43-69

Paalme T, Martin G, Kotta J, Kukk H, Kaljurand K (2004) Distribution and dynamics of drifting macroalgal mats in the Estonian coastal waters during 1995-2003. Proc Estonian Acad Sci Biol Ecol 53:260-268

Parker T, Johnson C, Chapman ARO (1993) Gammarid amphipods and littorinid snails have significant but different effects on algal succession in littoral fringe tidepools. Ophelia 38:69-88

Parker DM, Duffy JE, Orth JR (2001) Plant species diversity and composition: experimental effects on marine epifaunal assemblages. Mar Ecol Prog Ser 224:55-67

Pascoe D, Kedwards TJ, Blockwell SJ, Taylor EJ (1995) Gammarus pulex (L.) feeding bioassay-effects of parasitism. Bull Environ Contam Toxicol 55:629-632

Pavia H, Carr H, Åberg P (1999) Habitat and feeding preferences of crustacean mesoherbivores inhabiting the brown seaweed Ascophyllum nodosum (L.) Le Jol. and its epiphytic macroalgae. J Exp Mar Biol Ecol 236: $15-32$

Pinkster S, Scheepmaker M, Platvoet D, Broodbakker N (1992) Drastic changes in the amphipod fauna (Crustacea) of Dutch inland water during the last 25 years. Bijdr Dierk 61:193-204

Poore AGB (1994) Selective herbivory by amphipods inhabiting the brown alga Zonaria angustata. Mar Ecol Prog Ser 107:113-123

Rönnberg O, Ådjers K, Ruokolahti C, Bondestam M (1992) Effects of fish framing on growth, epiphytes and nutrient content of Fucus vesiculosus L. in the Aland archipelago, northern Baltic Sea. Aquat Bot 42:109-120

Salemaa H (1979) Ecology of Idotea spp. (Isopoda) in the Northern Baltic. Ophelia 18:133-150

Schiel RD (2004) The structure and replenishment of rocky shore intertidal communities and biogeographic comparisons. J Exp Mar Biol Ecol 300:309-342

StatSoft Inc. (2004) Electronic statistics textbook. StatSoft, Tulsa, OK. http://www.statsoft.com/textbook/stathome.html. Cited 2 Aug 2007 
Szaniawska A, Łapucki T, Normant M (2003) The invasive amphipod Gammarus tigrinus Sexton, 1939, in Puck Bay. Oceanologia 45:507-510

Timm T, Kangur K, Timm H, Timm V (1996) Macrozoobenthos of Lake Peipsi-Pihkva: long-term biomass changes. Hydrobiologia 338:155-162
Viejo RM (1999) Mobile epifauna inhabiting the invasive Sargassum muticum and two local seaweeds in northern Spain. Aquat Bot 64:131-149

Worm B, Sommer U (2000) Rapid direct and indirect effects of a single nutrient pulse in a seaweed-epiphyte-grazer system. Mar Ecol Prog Ser 202:283-288 